Universidade Tecnológica Federal do Paraná - UTFPR

Campus Ponta Grossa - Paraná - Brasil

ISSN: 1981-3686/ v. 08, n. 01: p. 1188-1207, 2014

D.O.I.: $10.3895 / \mathrm{S} 1981-36862014000100005$
Revista Brasileira de Tecnologia

Agroindustrial

\title{
REDUCTION OF THE CONTAMINATION IN THE PROCESSES OF FEED PRODUCTION USING THE SYSTEM OF HAZARD ANALYSIS AND CRITICAL CONTROL POINTS (HACCP)
}

\section{REDUÇÃO DAS CONTAMINAÇÕES NOS PROCESSOS DE PRODUÇÃO DA RAÇÃO UTILIZANDO O SISTEMA DE ANÁLISES DE PERIGOS E PONTOS CRÍTICOS DE CONTROLE (APPCC)}

\author{
Paulo Carteri Coradi ${ }^{1}$; Adílio Flauzino de Lacerda Filho ${ }^{2}$; José Benício Paes Chaves ${ }^{3}$, Reginaldo \\ Rodrigues dos Santos ${ }^{4}$ \\ ${ }^{2,3}$ Federal University of Viçosa - UFV - Viçosa - Brazil, alacerda@ufv.br, jbchaves@ufv.br \\ ${ }^{1}$ Federal University of Mato Grosso do Sul - UFMS - Chapadão do Sul - Brazil, \\ paulo.coradi@ufms.br \\ ${ }^{4}$ Feed Mill Pif Paf Foods, Visconde do Rio Branco, Minas Gerais, Brazil, \\ reginaldosanto@pifpaf.com.br
}

\begin{abstract}
Reduce contamination in feed industries is a big challenge for all the companies to get better products and to expand the consumer marketing. Thus, the aim of this study was to identify and evaluate contamination of a feed mill, suggesting a control plan based on the system of Hazard Analysis and Critical Control Points (HACCP). The experimental activities were conducted in a poultry feed facility with a capacity of 1,000 ton/day, located in Minas Gerais state, Brazil. The evaluation of the contamination was performed on flow corn, soybean meal, and feed production. After 72 hours of operation of the equipment, high levels of microbiological contamination were identified on the surface. The low physical quality of the products $(4.2 \%$ impurities, $15.83 \%$ w.b., aw 0.85) favored the development of insects (7), fungi $\left(1.2 \times 10^{7} \mathrm{CFU} \cdot \mathrm{g}^{-1}\right)$ and bacteria $\left(1.0 \times 10^{7} \mathrm{CFU} \cdot \mathrm{g}^{-1}\right)$ in batches grain, and animal byproducts. The high rate of contamination in raw materials enabled the formation of mycotoxins (aflatoxins of $60 \mathrm{ppb}$, 28 ppm of fumonisins) in the final products. In the steps of receiving and storage of raw materials showed the highest levels of microbiological contamination, increasing the risk of contamination of the feed end. It was concluded that the contamination physic-chemical and microbiological processing unit found in the diet adversely affect the quality of the finished feed. For quality control of products was necessary to monitor all stages of production since the arrival of the raw material until dispatch of the diets.
\end{abstract}

Key-words: industry; processing; products; quality.

\section{Introduction}

The poultry section inside of the agribusinesses chain, in the year of 2008 it made possible Brazil great representativeness in the international trade of chicken meats, with $35 \%$ of the production. In the international context the Brazil is the third largest producing of foods balanced for animals, behind only of the United States and China and, the largest producing of Latin America with $50 \%$ of the production (SINDIRAÇÕES, 2012). However, it was possible to observe that the poultry meat is one of the main products involved in foodborne infections because of its 
susceptibility to infection by pathogens, mainly molds and bacterial, as well as physical and mycotoxins contamination (ESCUDERO-GILETE et al., 2007; NORTHCUTT et al., 2003).

For reduce the contamination index and increase the quality of the products is need to stimulate the development of research with the objective of obtaining new methods, techniques and tools which allow for conservation and preservation of products (ROPKINS et al., 2000; SOFOS, 2008; TURHAN et al., 2006). To obtain high quality in the product a rigid work is necessary for evaluation and control in all phases of the production process, involving raw material, ingredients, packaging, equipment and operators (SURAK, 2002; TOMPKIN, 1994). There are various tools which an organization can use to improve its management, including Good Manufacturing Practices (GMP), Hazard Analysis and Critical Control Points (HACCP), Quality Management based on ISO 9000:2008 norm, Quality Management based on ISO 14000:1996 norm, the Occupational Safety and Health (OSH) systems, based on OHSAS 18001 regulations, the Integrated Management System (IMS), the SA 8000 (Social Responsibility) and the National Quality Prize Excellence Criteria (CODEX ALIMENTARIUS COMMISSION, 1996; NORTHCUTT et al., 2003).

The Hazard Analysis and Critical Control Points (HACCP) were elaborated to prevent microbiological, physical and chemical contamination problems (HOORNSTRA et al., 2001). This approach can be applied to all stages of the food process, ranging from production to processing, transport, commercialization in commercial establishments and/or direct utilization by the customer (CORADI et al., 2009; MORTIMORE, 2000; MOTARJEMI et al., 1999). To implement the HACCP system, it is fundamental to be well informed of the products and the operational procedures related to its processing, allowing for identification of the points where contamination could possible occurs and how to prevent it (NORTHCUTT et al., 2003). The HACCP system can be contributing to attend to pertinent legislation and federal inspections, as well as develop products of quality, reliable and certified, with minimal losses and reduced costs (HOORNSTRA et al., 2001; NORTHCUTT et al., 2003). The aim of this study was to identify and evaluate contamination of a feed mill, suggesting a control plan based on the system of Hazard Analysis and Critical Control Points (HACCP).

\section{Material and methods}

\section{Flow production of the products in the feed mill}

The experiment was conducted at a poultry feed facility with the capacity for production of 1,000 ton/day, located in Minas Gerais state, Brazil. The flow production of the feed mill starts with the weighing of the raw materials (Figure 1). Unloading of bulk products is performed in separated hoppers. For sacked raw materials, a manual system is utilized for unloading of individual units. 
Pre-cleaning of the grain consists of an air machine and a sieve with a capacity of 600 ton $^{-1}$ in which light impurities are removed by the air. Impurities and damaged grains are separated in the sieve based on different forms, considering the perforation standards of the sieve and the quality standards adopted by the industry. Grain drying is performed in a continuous flow dryer with a nominal capacity of 60 ton $\mathrm{h}^{-1}$. The product is transported within the mill by bucket elevators, belt conveyers and screw augers. Storage units consist of eight metallic silos, four with capacities of 1,200 tons each and the other four each capable of storing 2,100 tons.

For corn storage between harvests, another eight silos with capacities of 200 tons each can be utilized. At the harvest peak, these silos are used for drying (aeration systems). Soybean meal is stored in two cement silos with capacities of 350 tons each. Another six metallic silos of 100 tons are also used for storage of soybean meal. Micro ingredients, including methionine, lysine, lime, salt, sodium bicarbonate, premixes, vitamins and rice and wheat meals, specifically, are stored in an internal area of the mill (Figure 2). Weighing of these ingredients is done manually and they are mixed in a pre-mixer. The ingredient mixing system for feed production is composed of a premixer, mixers and a hopper bin, with a capacity for 4,000 Kg.

The system is operated and controlled automatically by a computer. Weighing and addition of ingredients is done in a hopper for receiving of meals, doser and doser bins, oil (fat) tanks and a weighing scale. The control system is automatic and computerized for addition of the following products: soybean meal, wheat meal, corn germ, feather, viscera and meat meals and viscera oils according to the specific feed recipe. After weighing and the addition of the ingredients, the products are ground simultaneously. The grinding system is composed of hammer mills, each with a rated power of $128.0 \mathrm{~kW}$. Pelletization is performed with pelletizers presenting capacities of 25 tons each, operating at a temperature and pressure on the order of $73{ }^{\circ} \mathrm{C}$ and $750 \mathrm{Kgf} \mathrm{m}^{-2}$, respectively. After formation, the pellets are cooled to remove excess moisture and heat. The loading system of feed is in bulk, utilizing hopper bins and storage silos, with capacities of 60 tons each. 


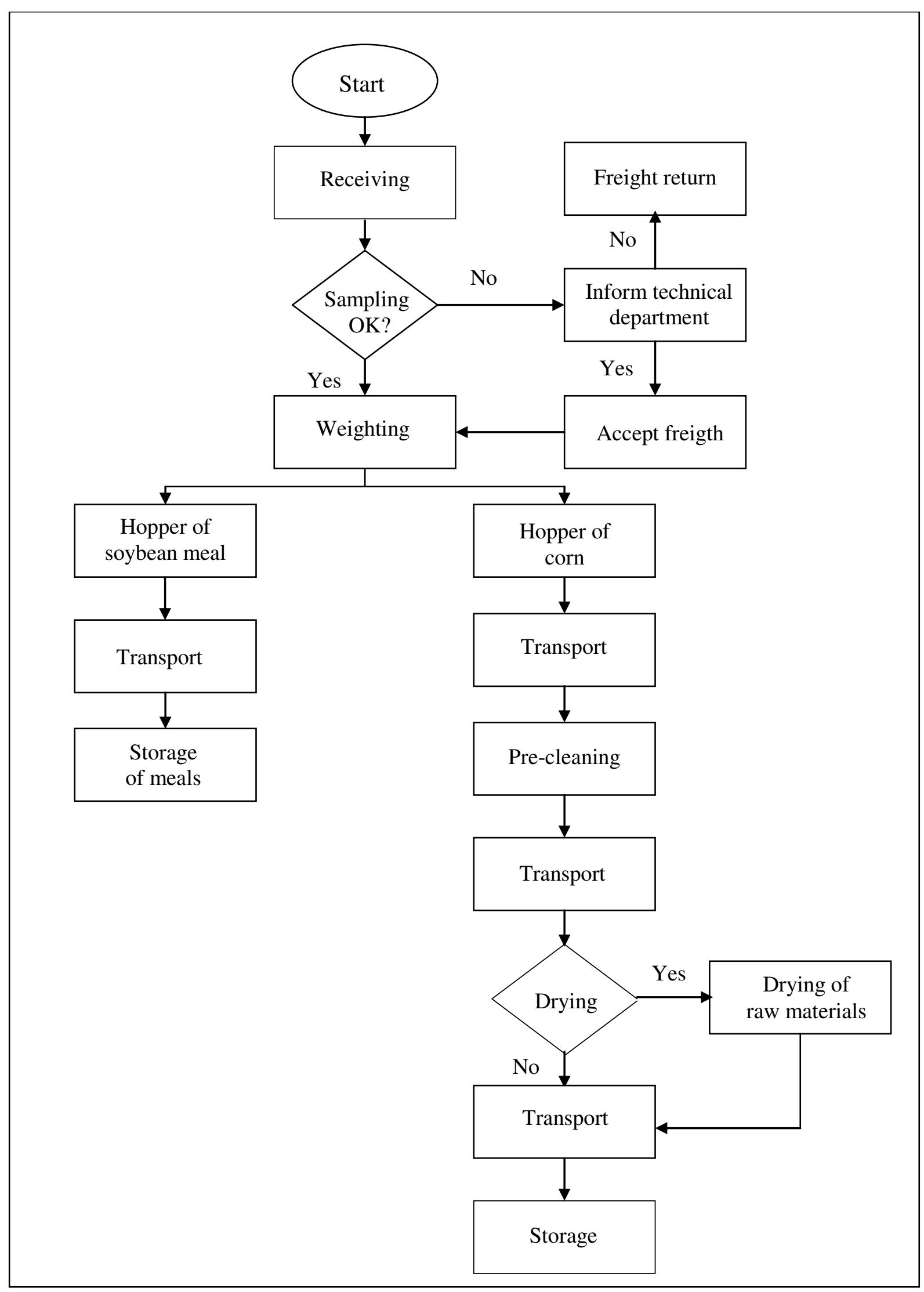

Figure 1 - Processing and storage of raw materials 


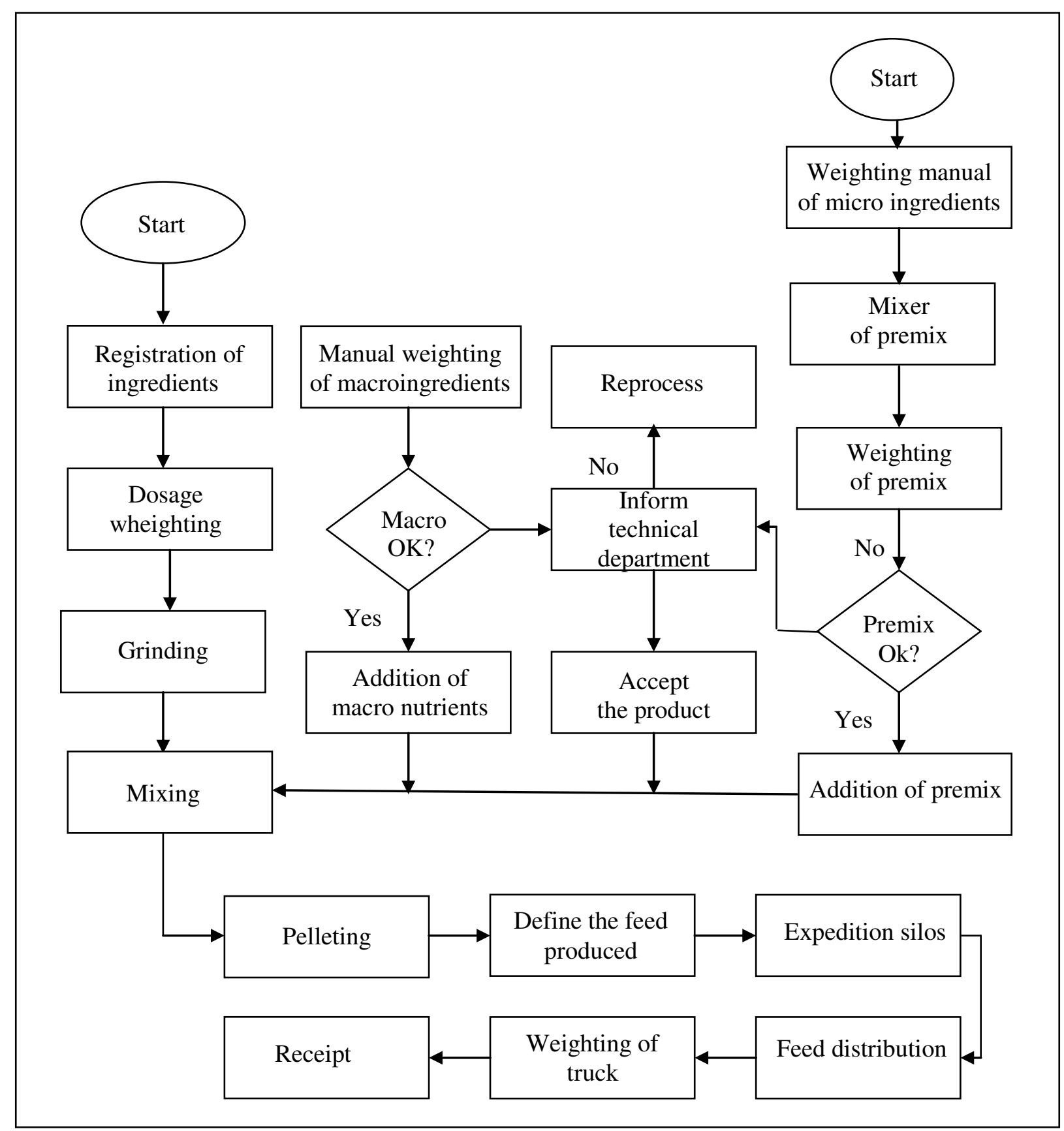

Figure 2 - Feed industrialization

Discharge is done directly in bulk feed trucks. The entire product transportation system in the feed mill is continuous. The grains, soybean meal and other meals arrive at the feed mills by means of bulk trucks. Wheat and rice meals, as well as other micro ingredients such as premixes and vitamins, are transported to the mill in trucks suited for transport of sacked feeds.

\section{Application of the HACCP principles}

Application of the HACCP principles was performed, considering a logical sequence of operations according to the methodology described by FAO (2001). For each step of the processes of feed production were identified the biological, chemical, and physical hazards, significant to 
quality of the products (principle 1). For the identification of the critical control points-CCP (principle 2) was utilized as tool the diagram adapted from Codex Alimentarius. For each critical point control was established the limits critical (principle 3); the procedures of control (principle 4); the corrective action (principle 5); the procedures of verification (principle 6) and the registers (principle 7).

\section{Sampling of raw materials and feed processed}

Samples of corn, flours and feed were collected in the receiving, storing, processing, and expedition steps. In the sectors of receiving of the feed mill, the products were sampled within the transport trucks. Samples of products were collected at the exit of the conveyor belts at the entrance of bucket elevators and screw conveyors. Samples were collected before and after storage of corn and soybean meal, the same was done for the stages of pre-cleaning and drying corn. In the industrialization of feed, product samples were collected at the end of grinding, mixing, pelleting and delivery. To collect samples of products in the sectors receiving and storage were used equipments "auger type". The auger-type compounds were used to collect samples of bulk products and the auger-type manual for the products in bags. In handling equipment product and the stages of pre-cleaning, drying, grinding, mixing, pelleting and delivery, samples were collected at the exit gates. The corn grains transported in trucks were sampled at different points of the load and the number of points was determined by the size of the lot, according to the rules described in BRAZIL (1996). In an amount of less than 100 tons of corn, $20 \mathrm{Kg}$ of product was sampled, while quantities of corn above 100 tons, samples of $15 \mathrm{Kg}$ for each 100 tons were collected. According to BRAZIL (1996), the sampling of the vegetable meals was performed with the removal of samples of $10 \mathrm{Kg}$ to 10 tons each. There is no official methodology to describe the sampling procedures of animal meals for use in feed formulation. So, it was decided collected $10 \mathrm{Kg}$ of product to 10 tons each. In all stages of industrialization and expedition of feed it was collected a total of $45 \mathrm{Kg}$ sample for each 1,000 ton/day processed, following the standards recommended by the Analytical Laboratory Mycotoxicology (LAMIC), Universidade Federal de Santa Maria. All grains samples were homogenized, reduced and divided into three parts using equipment separated. The samples were weighed and properly identified in plastic bags. Feeds, vegetable meals, and animal meals were divided into three parts of a $1 \mathrm{~kg}$ each, and properly identified and packaged in plastic bags. All samples, in triplicate, were sent to the laboratory for physical-chemical and microbiological.

Quantitative factors were analyzed using the Sisvar $4.3^{\circledR}$ program for mean comparison by the Tukey test at $5 \%$ probability. 


\section{Foreign materials and impurities in corn grains}

The quantification of foreign materials and impurities in corn grains was realized in $250 \mathrm{~g}$ of products. The sample of corn was passed in a sieve with holes of five millimeters in diameter according to the criteria described in the Administrative Rule (BRAZIL, 2009). Products that exceeded the tolerance of foreign materials and impurities were framed as "below of the standard".

\section{Determination of the water content in the grains corn}

The water content (\% w.b.) was determined in the quality sector, the indirect method, using the meter moisture Geole (G-800) after being calibrated with the official from the oven, set at 103 ${ }^{\circ} \mathrm{C} \pm 2{ }^{\circ} \mathrm{C}$ for $24 \mathrm{~h}$. Tests were performed with samples of $50 \mathrm{~g}$ in three replicates, according to recommendations contained in Rule for Seed Analysis (BRAZIL, 2009). For each sample three replicates were performed.

\section{Determination of the water content in the flours and feeds}

For determination of water content in animal meals, and feed were performed the weighing of the capsules, previously cleaned and dried in an oven at $105{ }^{\circ} \mathrm{C}$ for one hour and cooled in a desiccator until room temperature. A sample of $5 \mathrm{~g}$ was weighed and placed in an oven preheated to $103{ }^{\circ} \mathrm{C} \pm 2{ }^{\circ} \mathrm{C}$ until constant weight (4 hours). After this time, the container was removed from the oven, cooled in a desiccator until equilibrium with the ambient temperature, and held the weight (AAFCO, 2003). For each sample three replicates were performed.

\section{Counting of insects}

The assessment of insects in the products was made by visual counting in $1 \mathrm{~kg}$ of product sampled (LORINI, 2002). The product sample collected from $1 \mathrm{~kg}$ was poured into a table, with artificial lighting, then pulled out with tweezers all the insects and the sample was made to count them. According to LORINI et al. (2002) low infestation was considered to be fewer than 6 insects; medium infestation up to 15 insects; and high infestation over 25 insects for sample of $1 \mathrm{Kg}$.

\section{Counting of mites}

The samples examined were first sieved through stainless steel mesh opening of $0.50 \mathrm{~mm}$ on a sheet of paper to separate the particles of dust mites in the sample. Mites were quantified under a stereomicroscope. All results were expressed in terms of $50 \mathrm{~g}$ of sample (HUGHES, 1976). 


\section{Counting of bacteria colonies}

Salmonella sp. was analyses using the general method described by the American Public Health Association American Public Health Association-APHA (SPECK, 1984). The material was incubated at $370{ }^{\circ} \mathrm{C}$ in a bacteriological incubator for 18 hours as pre-enrichment, for the initial isolation of Salmonella sp. Aliquots of $1 \mathrm{~mL}$ pre-enriched sample were inoculated in Muller Kauffmann tetrathionate broth (TMK) and incubated at $370{ }^{\circ} \mathrm{C}$ for $18 \mathrm{~h}$ for quantification. The black E. coli. colonies were identified by E.C. tubes with gas using agar plates and Eosin Methylene Blue-EMB $\left(35^{\circ} \mathrm{C} \pm 1{ }^{\circ} \mathrm{C}\right.$ for 24 hours). For Listeria monocytogenes analyses a serving of 25 grams of sample was weighed and homogenized in $225 \mathrm{~mL}$ of LEB broth (Listeria Enrichment Broth, UVM formulation, Oxoid) and incubated at $30^{\circ} \mathrm{C}$ for 24 hours. The $0.1 \mathrm{~mL}$ of this material was transferred into a tube containing $10 \mathrm{~mL}$ of Fraser Broth (Oxoid), which was incubated at $37{ }^{\circ} \mathrm{C}$ for 24 hours. The blackened Fraser Broths were plated on agar Palcan and Oxford (both Oxoid), and incubated at $37{ }^{\circ} \mathrm{C}$ for 24 hours. The colonies of Listeria monocytogenes were transferred to trypticase soy agar plates supplemented with $0.6 \%$ yeast extract (TSA-YE, both Oxoid) to verify its purity. The count of Clostridium perfringens and botulinum were performed in culture medium base Broth Trypcase Modified Soybeans-BTMS for one gram of sample. After, $10 \mathrm{~mL}$ of the suspension material were seeded in the BTMS. The plates were incubated under anaerobic conditions for $20 \mathrm{~h}$ at $35-37{ }^{\circ} \mathrm{C}$. All the analysis was performed in three replicates by the Colony Forming Units $\left(\right.$ CFU.g $\left.{ }^{-1}\right)$.

\section{Counting of fungi colonies}

The analysis of toxigenic fungi was performed by DHINGRA \& SINCLAIR (1995). Analyses were performed in triplicate and results were expressed as Colony Forming Unit per gram of contaminated products $\left(\mathrm{CFU} \cdot \mathrm{g}^{-1}\right)$. In the process of preparation of the samples was weighed $25 \mathrm{~g}$ in sterile stomacher bag (Seward Stomacher 400 Lab System, England), then mingled with $225 \mathrm{~mL}$ of the saline water and peptone $0.1 \%$, yielding so the $10^{-1}$ dilution. After sample homogenization, serial dilutions were performed up to $10^{-4}$ using test tubes with $9.0 \mathrm{~mL}$ of the same diluents. For the seeding process was used the technique of plating on the surface, through the use of medium Batata-Dextrose-Ágar acidified with $10 \%$ tartaric acid to a $\mathrm{pH}$ of 3.5. The material was pipetting to $0.1 \mathrm{~mL}$ of each sample dilution in sterile Petri dish containing $20 \mathrm{~mL}$ of culture medium acidified PDA and a Drigalski loop; spread the inoculums across the medium surface, then incubated at a temperature of $25^{\circ} \mathrm{C} \pm 1{ }^{\circ} \mathrm{C}$ for a period of four days. After this period, the colonies were quantified (CFU.g ${ }^{-1}$ ). 
Quantification of aflatoxins (ppb) and fumonisins (ppm) levels in the products

For each samples was quantified the total aflatoxins, and total fumonisins. The aflatoxins analyses were done by the methodology ELISA (Enzyne Linked Immunosorbent Assay) according recommendation of the commercial kit Romer Lab. (Agraquant) (USDA, 1998). A $25 \mathrm{~g}$ ground sample was extracted with $250 \mathrm{ml}$ of $70 \%$ methanol. The samples were allowed to settle, then the solvent was filtered through a Whatman \#1 filter paper and the filtrate was collected. Sample extract $100 \mu \mathrm{l}$ or aflatoxin test kit standard were mixed with $200 \mu \mathrm{l}$ of conjugate in individual dilution wells, and then $100 \mu \mathrm{l}$ from each dilution well was transferred to a respective antibody-coated microwell. After $15 \mathrm{~min}$ incubation at room temperature, the plates were washed 5 times with distilled water. Enzyme substrate $(100 \mu \mathrm{l})$ were added to each well, and allowed to incubate for an additional $5 \mathrm{~min}$. Stop solution (100 $\mu \mathrm{l}$ for each well) was then added and the intensity of the resulting yellow color will be measured optically with a microplate reader at a wavelength of 450 nm (Stat Fax 303 microwell readers, Awareness Technology Inc.). The fumonosins analysis procedure a dilution (1/20) of the sample in distilled water was used, and a time of 5 min incubation at room temperature, while the other steps the same aflatoxins procedure was utilized.

\section{Control of rodents and birds at the feed mill}

The monitoring of rats in the feed mill was accomplished with the installation of traps and application of product "raticide" in the form of "block", distributed by square meter of each section of the feed mill. In the same sections, the presence of birds was evaluated. Every two weeks the traps were inspected to verify the presence of signs of rodents as feces, urine, hair, consumed baits, live and dead rodents (MATIAS et al., 2002). The frequency of birds in the sectors was identified by the presence of feces, feathers, live birds and dead birds.

\section{Sanitation of the equipments}

The monitoring of the critical control points in the equipments of production was done on the elevators, auger conveyers and belt conveyers after 24, 72 and 216 hours of work. The hopper, pre-cleaning, drying, storage, and expedition were disinfected at 12, 48, and 84 hours. The steps of weighting, mixing, dosing, grinding, pelletizing, cooler, and truck were disinfected after 12, 24 and 36 hours. Some test preliminaries were done to define the time at which to collect the samples. The equipments cleaning proceeded with the renovation of the residual and stagnated products in the surface and in the corners of the equipment. The sampling in the equipment for analysis was preceded with the use of sterile swab for an area of $100 \mathrm{~cm}^{2}$. The operation was repeated three times for each equipment surface and in different points. In the end of the collection, the swab was put in 
a tube and covered with solution, identified and conditioned in special box for sending to laboratory for microbiological analysis.

\section{Results and discussion}

Microbiological contamination on the surfaces of the equipments

Assessing the surfaces of the equipment of the production system of feed, we identified a high rate of microbial contamination, highlighting the receiving systems and internal transport industry products (Tables 1 and 2).

Table 1 - Species of fungi and bacteria identified in the surface of the equipments

\begin{tabular}{lc}
\hline Species of fungi and bacteria identified & Symbols $^{1}$ \\
\hline Fusarium moniliforme & 1 \\
Fusarium verticilliodides & 2 \\
Fusarium proliferatum & 3 \\
Aspergillus candidus & 4 \\
Aspergillus flavus & 5 \\
Aspergillus tamarii & 6 \\
Penicillium duclauxii & 7 \\
Penicillium purpurogenum & 8 \\
Penicillium funiculosum & 9 \\
Clostridia perfringens & 10 \\
Clostridia botulinum & 11 \\
Listeria monocytogenes & 12 \\
Escherichia coli & 13 \\
Salmonellas sp. & 14 \\
\hline Identification of the species of microorganisms presents on the surface of the equipments, according to Table 2.
\end{tabular}

The high bacterial contamination observed in the Table 2, also can bring serious problems for poultry industry. Reducing the bacterial contamination in the final feed would be decreasing also gastric dilatation (primates), necrotic enteritis (poultry), and gangrenous dermatitis (turkeys) by the Clostridia botulinum (SCHOENBAUM et al., 2000); septicemia, abortions, encephalitis, and eye infections by the Listeria sp. (NIGHTINGALE et al., 2004); septicemia, cellulitis, swollen head, syndrome (poultry), and airsaculitis by the Escherichia coli (MILLER et al., 2004); enteritis, diarrhea, and septicemia by the Salmonella sp. (PATRICK et al., 2004). 
Table 2 - Species of fungi and bacteria isolated from surface of the equipments

\begin{tabular}{|c|c|c|c|c|c|c|}
\hline \multirow{2}{*}{$\begin{array}{l}\text { Flow } \\
\text { Production }\end{array}$} & \multicolumn{6}{|c|}{ Dilutions (APDCB) } \\
\hline & $10^{-1}$ & $10^{-2}$ & $10^{-3}$ & $10^{-4}$ & $10^{-5}$ & $10^{-6}$ \\
\hline \multicolumn{7}{|l|}{$\operatorname{Corn}^{\mathrm{a}}$} \\
\hline Elevators & $2 / 6 / 8$ & $4 / 5 / 7$ & $4 / 5 / 6 / 7 / 11$ & $1 / 5 / 6 / 9$ & $4 / 5 / 6 / 7$ & $4 / 6 / 8$ \\
\hline Auger conveyers & $4 / 6 / 9 / 10$ & $4 / 6 / 9 / 13$ & $1 / 4 / 8 / 11$ & $5 / 7 / 8 / 13$ & $6 / 5 / 8 / 13$ & $4 / 6 / 7$ \\
\hline Belt conveyers & $4 / 5 / 7 / 13$ & $1 / 5 / 7$ & $6 / 4 / 9 / 13$ & $3 / 5 / 7$ & $4 / 5 / 7$ & $4 / 9 / 13$ \\
\hline Weighing & $1 / 2 / 4 / 6 / 8$ & 2/5/6/9/12 & $1 / 4 / 6 / 7$ & $1 / 3 / 6 / 8$ & $4 / 6 / 7 / 12$ & $3 / 4 / 6 / 8$ \\
\hline Hopper & $1 / 3 / 6 / 8 / 10 / 13$ & $1 / 3 / 5 / 7$ & $1 / 3 / 5 / 8 / 13$ & 2/4/5/7/11 & $1 / 3 / 6 / 7 / 13$ & $2 / 4 / 8$ \\
\hline Pre-cleaning & $2 / 6 / 7$ & $2 / 3 / 4 / 6$ & $1 / 2 / 5 / 7$ & $3 / 5 / 9$ & $1 / 5 / 7 / 8$ & $1 / 2 / 4 / 9$ \\
\hline Drying & $1 / 4 / 7$ & $1 / 4$ & $1 / 5$ & $2 / 3 / 8$ & $3 / 5 / 8$ & $2 / 5 / 8 / 9$ \\
\hline Storage silos & $1 / 4 / 5 / 6 / 7 / 8 / 11$ & $3 / 5 / 6 / 8 / 13$ & $2 / 4 / 5 / 9 / 12$ & $3 / 5 / 7 / 11 / 12$ & $2 / 4 / 9 / 13$ & $1 / 5 / 6 / 8$ \\
\hline \multicolumn{7}{|l|}{ Soybean meal $^{b}$} \\
\hline Elevators & $6 / 8 / 9$ & $3 / 4 / 7 / 9$ & $4 / 5 / 7 / 12$ & $1 / 4 / 6 / 7$ & $2 / 5 / 6 / 7 / 8$ & $3 / 5 / 7 / 8$ \\
\hline Auger conveyers & $2 / 5 / 8 / 11 / 13$ & $3 / 4 / 7$ & $1 / 3 / 9 / 13$ & $1 / 8 / 9 / 12$ & $4 / 6 / 9 / 11$ & $3 / 6 / 7 / 9$ \\
\hline Belt conveyers & $2 / 6 / 8 / 12$ & $1 / 5 / 7 / 13$ & 2/3/7/9/11 & 2/5/7/8/11 & $2 / 3 / 5 / 7 / 10$ & 4/7/9/12 \\
\hline Weighing & $1 / 4 / 7$ & $4 / 5 / 10 / 12$ & $2 / 4 / 6 / 7 / 13$ & 2/3/6/9/12 & $4 / 5 / 7 / 12$ & $3 / 6 / 8 / 11$ \\
\hline Hopper & $1 / 2 / 5 / 9 / 10 / 11$ & $1 / 2 / 5 / 7 / 12$ & $1 / 2 / 4 / 9 / 13$ & $2 / 3 / 4 / 8 / 10$ & $1 / 2 / 5 / 7 / 13$ & $2 / 4 / 7 / 10$ \\
\hline Storage silos & $1 / 2 / 5 / 7 / 11$ & $3 / 5 / 6 / 8$ & $2 / 4 / 9 / 12$ & 4/7/10/12 & $3 / 9 / 12$ & $1 / 4 / 7 / 8 / 13$ \\
\hline \multicolumn{7}{|l|}{ Feed $^{c}$} \\
\hline Elevators & 2/4/6/7/12 & $1 / 5 / 7 / 8 / 13$ & $5 / 6 / 7 / 9 / 12$ & $1 / 4 / 5 / 8 / 10$ & $1 / 4 / 8 / 9 / 11$ & $2 / 4 / 7 / 9 / 13$ \\
\hline Auger conveyers & 2/4/8/9/11/13 & $3 / 5 / 7 / 11 / 13$ & $2 / 4 / 7 / 8 / 13$ & $2 / 7 / 8 / 12 / 13$ & $2 / 7 / 8 / 11 / 12$ & $1 / 5 / 8 / 9 / 13$ \\
\hline Belt conveyers & $2 / 6 / 8 / 12$ & $1 / 5 / 7 / 13$ & $2 / 3 / 7 / 9 / 11$ & 2/5/7/8/11 & $2 / 3 / 5 / 7 / 10$ & $4 / 7 / 9 / 12$ \\
\hline Weighing micros & $8 / 10 / 12 / 13 / 14$ & $12 / 13 / 14$ & $8 / 9 / 11 / 13$ & $7 / 9 / 10 / 12$ & $8 / 9 / 12 / 13$ & $9 / 11 / 13$ \\
\hline Weighing macros & $2 / 6 / 7 / 10 / 13$ & $3 / 5 / 8 / 12$ & $4 / 6 / 7 / 13$ & $6 / 7 / 8 / 10 / 12$ & $10 / 12 / 13$ & $9 / 11 / 13$ \\
\hline Premix weighing & $11 / 12 / 13 / 14$ & $12 / 13 / 14$ & $12 / 13 / 14$ & $13 / 14$ & $12 / 13$ & $10 / 13$ \\
\hline Weighing & $10 / 11 / 13 / 14$ & $7 / 12 / 14$ & $13 / 14$ & $12 / 13 / 14$ & $12 / 13$ & 13 \\
\hline Premix mixing & $13 / 14$ & $11 / 13 / 14$ & $10 / 12$ & 13 & $13 / 14$ & 12 \\
\hline Grinding & $2 / 7 / 8 / 9 / 13 / 14$ & $3 / 7 / 8 / 10 / 14$ & $9 / 11 / 14$ & $8 / 10 / 12 / 13$ & $8 / 13$ & $7 / 12 / 13$ \\
\hline Mixing & $7 / 10 / 12 / 14$ & $9 / 10 / 11 / 13$ & $8 / 10 / 12 / 13$ & $8 / 9 / 11 / 13$ & $10 / 13$ & $11 / 12 / 13$ \\
\hline Pelletizing & $10 / 13$ & 13 & 11 & 10 & 12 & 13 \\
\hline Cooling & $9 / 13 / 14$ & $7 / 10 / 14$ & $13 / 14$ & $11 / 12 / 14$ & $10 / 13$ & 8 \\
\hline Expedition & $7 / 8 / 13 / 14$ & $8 / 10 / 13$ & $8 / 12 / 14$ & $10 / 11 / 13$ & $9 / 13$ & 9 \\
\hline Truck & $2 / 4 / 7 / 11$ & $3 / 6 / 8 / 11 / 13$ & $1 / 6 / 7 / 10 / 13$ & $2 / 5 / 9 / 11 / 13$ & $2 / 4 / 8 / 12$ & $1 / 5 / 10 / 13$ \\
\hline
\end{tabular}

The presence of species of fungi and bacteria on surfaces of equipment indicated possible contamination of raw materials and processed feed. To avoid cross-contamination in the production system, first elaborated a program of cleaning and disinfection of the industry (Table 3). 
Table 3 - Application HACCP system

\begin{tabular}{cc}
\hline Process steps & Critical limits \\
\hline Elevators & Corn-72 hours \\
& Soybean meal-72 hours \\
Feed-72 hours \\
Auger & Corn-72 hours \\
conveyers & Soybean meal-72 hours \\
Felt & Feed-72 hours \\
\hline conveyers & Corn-216 hours \\
& Soybean meal-72 hours \\
Weighing & Feed-72 hours \\
\hline Hopper & Feed-12 hours \\
& Corn-72 hours \\
\hline Pre-cleaning & Soybean meal-72 hours \\
Drying & Feed-72 hours \\
Storage silos & Corn-216 hours \\
& Corn-216 hours \\
\hline Mixing & Corn-72 hours \\
\hline Dosing & Soybean meal-72 hours \\
Grinding & Feed-72 hours \\
Pelletizing & Feed-12 hours \\
Cooling & Feed-12 hours \\
\hline Expedition & Feed-12 hours \\
Truck & Feed-48 hours \\
\hline Feed-12 hours \\
\hline
\end{tabular}

Thus, the equipments of the flow production were disinfected after 12, 24, 48, 72, 84 and 216 hours worked for decontamination. In the flow of corn observed increase of molds soon in the firsts 24 hours of work of the equipments. However, the higher contamination indexes were observed only in 72 hours of work. In 216 hours, the contamination indexes in the equipments constantly increased. In the equipments of pre-cleaning and drying, the indexes of contamination were lower than other steps of the processing. In these sectors, the Aspergillus sp. and Penicilium sp. prevailed among the species of fungi, as well the Clostridia sp., Escheridia sp. and Listeria sp. among the species of bacteria. In the systems of transport of the industry, soon at 72 hours of the work was identified contamination. In 216 hours a high contamination index by Clostridia sp., Escheridia sp. and Listeria sp. also was observed. The hoppers and storage silos of whole corn were the equipments most infected by microorganisms. Similar results were observed in the flow production of the soybean meal. However in the flow production of the feed, the presence of Salmonellas sp. was verified in 216 hours of work of the equipments. In the steps of weighting, mixing, grinding, dosing, pelletizing, cooling, expedition of the feed the results were similar, increasing the microbiological contamination indexes after 12 hours. For all the equipments were determined the correct time to clean and disinfect (Table 3 ). 


\section{Contamination of the products}

In industry and processing of grain ration, the quality of products is related to their appearance, uniformity, sanitary conditions, nutritional status, and industrial characteristics (CORADI et al., 2011). According to Table 4 high microbiological contamination levels was present in the products from different steps of production of the feed mill. It was observed that there was an increased contamination sampled along the flow $(\mathrm{p}>0.05)$. Among the major insect pests found in the products are Sitophilus zeamais and Tribolium sp. It was observed in the sample, aggregated distribution of insect pests in the mass of products. It was also found, variability in the amount of insect pests, among samples of the same product place and between silos (Table 4).

Table 4 - Microbiological contamination of the products on the flow production of the feed industry

\begin{tabular}{|c|c|c|c|c|c|c|c|}
\hline Prod. & Sector & $\begin{array}{c}\text { Water } \\
\text { content } \\
(\% \text { w. b. })^{1}\end{array}$ & $\begin{array}{c}\text { Activity } \\
\text { water } \\
\text { (a.w.) }^{1}\end{array}$ & $\begin{array}{c}\text { Fungi } \\
\left(\mathrm{CFU}^{-1}\right)^{1}\end{array}$ & $\begin{array}{c}\text { Bacteria } \\
\left.\left(\mathrm{CFU}^{-1}\right)^{1}\right)^{1}\end{array}$ & $\begin{array}{c}{ }^{2} \text { Numbers } \\
\text { of insects / } \\
\text { SD* }\end{array}$ & $\begin{array}{c}\text { Present } \\
\text { of } \\
\text { mites }\end{array}$ \\
\hline Corn & Reception & 14.30 & 0.68 & $2.0 \times 10^{3} \mathrm{~b}$ & $3.2 \times 10^{3} \mathrm{~b}$ & $3 \pm 1$ & - \\
\hline Corn & Hopper & 15.23 & 0.76 & $8.0 \times 10^{3} \mathrm{~b}$ & $6.5 \times 10^{5} \mathrm{~d}$ & $7 \pm 2$ & + \\
\hline Corn & Pre-cleaning & 14.40 & 0.76 & $9.1 \times 10^{4} \mathrm{c}$ & $7.2 \times 10^{4} \mathrm{c}$ & $3 \pm 1$ & + \\
\hline Corn & Drying & 11.89 & 0.66 & $2.1 \times 10^{1} \mathrm{a}$ & $1.6 \times 10^{2} \mathrm{a}$ & $2 \pm 1$ & - \\
\hline Corn & Elevators & 17.40 & 0.85 & $1.3 \times 10^{7} \mathrm{e}$ & $1.3 \times 10^{7} \mathrm{e}$ & $6 \pm 2$ & + \\
\hline Corn & Belt conveyers & 14.45 & 0.72 & $8.2 \times 10^{3} \mathrm{~b}$ & $9.4 \times 10^{3} \mathrm{~b}$ & $4 \pm 1$ & + \\
\hline Corn & Auger conveyers & 14.50 & 0.74 & $5.6 \times 10^{3} \mathrm{~b}$ & $3.7 \times 10^{5} \mathrm{~d}$ & $3 \pm 1$ & + \\
\hline Corn & Silos & 14.20 & 0.77 & $1.3 \times 10^{5} \mathrm{~d}$ & $5.1 \times 10^{5} \mathrm{~d}$ & $7 \pm 2$ & + \\
\hline Corn & Floor & 16.50 & 0.85 & $1.4 \times 10^{5} \mathrm{~d}$ & $4.1 \times 10^{5} \mathrm{~d}$ & $29 \pm 3$ & + \\
\hline Flours & Reception & 13.46 & 0.69 & $3.7 \times 10^{2} \mathrm{a}$ & $2.1 \times 10^{1} \mathrm{a}$ & $2 \pm 1$ & - \\
\hline Flours & Hopper & 14.76 & 0.75 & $1.6 \times 10^{3} \mathrm{~b}$ & $4.2 \times 10^{3} \mathrm{c}$ & $5 \pm 1$ & + \\
\hline Flours & Elevators & 14.82 & 0.77 & $1.4 \times 10^{5} \mathrm{c}$ & $3.1 \times 10^{5} \mathrm{~d}$ & $3 \pm 1$ & + \\
\hline Flours & Belt conveyer & 13.35 & 0.75 & $5.5 \times 10^{5} \mathrm{c}$ & $3.5 \times 10^{5} \mathrm{~d}$ & $4 \pm 1$ & + \\
\hline Flours & Auger conveyer & 15.21 & 0.81 & $1.2 \times 10^{7} \mathrm{~d}$ & $1.0 \times 10^{7} \mathrm{e}$ & $6 \pm 2$ & + \\
\hline Flours & Metal silos & 14.98 & 0.77 & $1.5 \times 10^{5} \mathrm{c}$ & $2.1 \times 10^{5} \mathrm{~d}$ & $3 \pm 1$ & + \\
\hline Flours & Cement silos & 12.56 & 0.70 & $5.5 \times 10^{2} \mathrm{a}$ & $3.8 \times 10^{2} \mathrm{~b}$ & $5 \pm 1$ & + \\
\hline Flours & Floor & 14.86 & 0.73 & $2.0 \times 10^{5} \mathrm{c}$ & $1.3 \times 10^{5} \mathrm{~d}$ & $26 \pm 3$ & + \\
\hline Feed & Grinding & 13.54 & 0.70 & $1.9 \times 10^{3} \mathrm{c}$ & $2.5 \times 10^{3} \mathrm{c}$ & 0 & + \\
\hline Feed & Mixing & 13.41 & 0.73 & $6.8 \times 10^{3} \mathrm{c}$ & $5.6 \times 10^{4} \mathrm{~d}$ & 0 & + \\
\hline Feed & Pelletizer & 11.15 & 0.71 & $6.0 \times 10^{1} \mathrm{a}$ & $1.0 \times 10^{1} \mathrm{a}$ & 0 & - \\
\hline Feed & Dispatch feed & 12.18 & 0.71 & $1.3 \times 10^{2} \mathrm{~b}$ & $2.2 \times 10^{2} \mathrm{~b}$ & $1 \pm 1$ & + \\
\hline Feed & Dispatch pellets & 11.31 & 0.71 & $1.7 \times 10^{2} \mathrm{~b}$ & $8.7 \times 10^{1} \mathrm{a}$ & 0 & - \\
\hline Feed & Bulk trucks & 13.43 & 0.69 & $3.9 \times 10^{2} \mathrm{~b}$ & $4.3 \times 10^{2} \mathrm{~b}$ & $2 \pm 1$ & + \\
\hline Feed & Floor & 14.21 & 0.70 & $4.0 \times 10^{5} \mathrm{~d}$ & $5.0 \times 10^{4} \mathrm{~d}$ & $18 \pm 3$ & + \\
\hline
\end{tabular}

With the variation of water content in the mass of products, found in some industrial areas, further development of insect pests. In general, it was observe damage caused by insects, resulting in loss of quality and quantity. The major losses caused by pests were weight loss, loss of nutritional value due to the penetration of other organisms, as mites and fungi, through holes left by insects (JIAN et al., 2009). According to DAL BELLO et al. (2001), generally, the larvae of the insects feed preferentially on endosperm or germ of the products, reducing then significantly protein and vitamin food. However, NUKENINE et al. (2002) affirm that Sitophilus zeamais can reduce up 
to $89.2 \%$ of grains in traditional systems of storage during campaign. To conserve the quality of the grain, it is necessary to fight against these devastating insects, using chemical insecticides (methyl bromide, acids, ozone and fosfine gas) and biological products associated the natural conditions of control (PARK et al., 2008). The conditions of the products, regarding the contents and water activity (Table 4) allowed after the infestation of insects, the development of fungi and bacteria. The fungi of the genera Fusarium, Aspergillus and Penicillium were the main microorganisms (Table 4) responsible by the contamination of the products and mycotoxins production (MARTINEZ et al., 2012) (Table 5).

Corn was the main commodity affected by the microorganisms that produced the toxins. However, soybean flours, in general, were excellent substrates that enhance mould growth, which in turn can cause direct losses and risks for human and animal health via production of allergen and toxin (MILICEVIC et al., 2010). According to MILICEVIC et al. (2010) the major fungus to produce aflatoxins, including aflatoxins B1, B2, G1 and G2, are the Aspergillus flavus. The major producer, Fusarium verticillioides is capable of producing the fumonisins, mainly B1, B2, and B3 (DUNCAN et al., 2010). The high concentrations of mycotoxins found on the products (Table 5) adversely affect the quality of the feed end and can then interfere with the development of animal food. Animals exposed to mycotoxins levels can produce a wide range of symptoms. Low concentrations of several mycotoxins have been shown to reduce weight gain, reduce litter sizes, deform offspring, reduce egg production, and reduce milk production (PETTERSSON, 2004).

The results obtained in the Tables 4 and 5 are justify by bulk of grain, instead it was not homogeneous, containing gradients of oxygen, carbon dioxide, nitrogen, moisture, temperature, and quantities of dockage and has distinct physical and biological properties. A grain ecosystem consisted of non-living and living factors. The result of the interaction among factors in grain ecosystem evaluated was the consumption and decomposition in grain ecosystem of the lots.

Table 5 - Identification of mycotoxins in the products

\begin{tabular}{llcc}
\hline Products & Sectors & ${\text { Aflatoxins }(\mathrm{ppb})^{1}}^{1}$ & ${\text { Fumonisins }(\mathrm{ppm})^{1}}^{1}$ \\
\hline Corn & Reception & $15.2 \mathrm{~d}$ & $28.6 \mathrm{~d}$ \\
Corn & Storage & $60.3 \mathrm{e}$ & $23.1 \mathrm{c}$ \\
Flours & Reception & $2.3 \mathrm{a}$ & $3.1 \mathrm{~b}$ \\
Flours & Storage & $2.5 \mathrm{a}$ & $2.9 \mathrm{~b}$ \\
Feed & Dispatch feed & $10.2 \mathrm{c}$ & $2.3 \mathrm{~b}$ \\
Feed & Dispatch pellets & $7.8 \mathrm{~b}$ & $1.2 \mathrm{a}$ \\
\hline \multicolumn{2}{l}{ Average of the results (number of samples evaluated according to Table 3). Averages followed by same } \\
\multicolumn{2}{l}{ letter in the in columns does not differ at 5\% probability. }
\end{tabular}

During this transformation of lots-grain ecosystems, volatiles, insects or their body fragments and fungal metabolite was present. Gas concentration, and grain temperature and moisture content changed (Table 4). These physical, chemical, and biological changes are used to 
control and monitor the quality of the stored grain (JIAN et al., 2012). Even though some volatiles produced by insects (SENTHILKUMAR et al., 2012), fungi, and grain (MYERS et al., 2012) are detected under controlled laboratory condition, it is not very clear as to which and how many chemicals are produced inside stored grain bins (Table 5).

The artificial environment created in the warehouses of products favored the development of mites (Table 4). In the mite infestation were probably carried by rodents, birds and insects that were present or in contact with the mass of products, related to, among other factors, the degree of cleaning products (Table 6).

Table 6 - Quantification of foreign materials and impurities in corn grains

\begin{tabular}{lccc}
\hline Sectors & $\begin{array}{c}\text { I Foreign materials (\%) / } \\
\text { standard deviation }\end{array}$ & $\begin{array}{c}{ }^{1} \text { Impurities (\%) / } \\
\text { standard deviation }\end{array}$ & $\begin{array}{c}\text { Total (Foreign materials }+ \\
\text { impurities) / standard deviation }\end{array}$ \\
\hline Reception of corn & $1.1 \pm 0.3$ & $3.1 \pm 0.4$ & $4.2 \pm 0.4$ \\
Hopper of corn & $1.2 \pm 0.2$ & $2.8 \pm 0.3$ & $4.0 \pm 0.3$ \\
Pre cleaning of corn & $1.0 \pm 0.1$ & $2.8 \pm 0.3$ & $3.8 \pm 0.2$ \\
Drying of corn & $0.4 \pm 0.1$ & $1.3 \pm 0.1$ & $1.7 \pm 0.1$ \\
Storage of corn & $0.5 \pm 0.1$ & $1.3 \pm 0.2$ & $1.8 \pm 0.2$ \\
Expedition of corn & $0.3 \pm 0.1$ & $1.2 \pm 0.2$ & $1.5 \pm 0.2$ \\
\hline Average of the results (samples of 250g were evaluated according Table 3). Samples of corn with $\geq 1.5 \%$ of Foreign \\
materials + impurities = corn type 1; samples of corn with $\geq 2.0 \%$ of foreign materials + impurities $=$ corn type 2; Samples \\
of corn with $\geq 3.0 \%$ of foreign materials + impurities = corn type 3; Samples of corn with $\leq 3.0 \%$ of foreign materials + \\
impurities = corn out standard.
\end{tabular}

The presence of impurities in the areas of production, and high rate of debris and foreign matter in the raw material batches (Table 6) was added to increase the rodent infestation in the industry (Table 7). The great diversity of rodent species, storage structures, and environmental conditions and the difficulty in estimating incremental or indirect losses help mask the economic impact of the problem. Since most rodent species involved in stored product damage are nocturnal, heavy infestations may persist unnoticed without careful inspection of stores or premises. In many situations, careful grain handling procedures, indoor and outdoor sanitation, immediate disposal of spillage and garbage, frequent inspection for rodent signs, and maintenance control programs are important ways to prevent the development of more serious and difficult problems (SUBRAMANYAM et al., 2005). The high infestation of birds is always very evident in feed mills.

Table 7 - Distribution of traps for rodent control in the feed industry

\begin{tabular}{lccc}
\hline $\begin{array}{l}\text { Evaluated } \\
\text { sectors }\end{array}$ & $\begin{array}{c}\text { Area } \\
\left(\mathrm{m}^{2}\right)\end{array}$ & $\begin{array}{c}\text { Number of } \\
\text { installated traps }\end{array}$ & $\begin{array}{c}\text { Number average of } \\
\text { rodents / SD* }\end{array}$ \\
\hline Portaria (receiving) & 80 & 2 & $6 \pm 2$ \\
Feed production & 1000 & 25 & $9 \pm 2$ \\
Hopper of corn & 120 & 3 & $14 \pm 3$ \\
Hopper of flours & 120 & 3 & $10 \pm 2$ \\
Storage of corn & 1200 & 30 & $20 \pm 3$ \\
Storage of flours & 295 & 7 & $14 \pm 3$ \\
Pre-cleaning corn & 36 & 1 & $7 \pm 2$ \\
Drying of corn & 34 & 1 & $8 \pm 3$ \\
\hline Time of evaluation (4 months). The traps were verified weekly $(n=16$ verification). *(Standard Deviation).
\end{tabular}


During the evaluation it was found the presence of feathers and feces in all sectors of industry, dead birds were found in elevator pits, bins and storage of corn, bran and feed, giving signals would be contaminated with mycotoxins. An integrated pest management plan is necessary to tackle a bird problem (SUBRAMANYAM et al., 2005). There are five basic approaches in managing a bird population. These include survey, sanitation, exclusion and habitat alteration, repellents, and population reduction. Surveys are necessary to identify the bird species and to study their activity patterns. Sanitation involves limiting or reducing access to food, water and shelter, in addition to regular removal of nests. Frequent clean up of spilled grain outside feed manufacturing plants is difficult and impractical. However, an effort should be made to change practices that cause grain spillage. Cleaning clogged drains, leaks, and standing water on roofs will help remove a water source. Persistent destruction of nests will greatly reduce populations of sparrows and pigeons. The objective of exclusion is to deny access to enter or use the building as a nesting, roosting or loafing site.

Plastic bird nets, covers, or ramps can be used to keep birds out of certain areas (Table 8). The way a building is designed will provide harborage for large populations of birds. Therefore, building modifications play an important role in bird management. Various kinds of repellents are available that can either scare the birds away or make it difficult for them to use the building as a nesting or roosting site. Different wires, such as porcupine wires, bird barrier coils, spikes, electrically charged wires, and piano string have been used to physically prevent birds from nesting and roosting. Sticky substances have been used, in certain situations, to repel birds. Population reduction is mainly achieved by the use of toxic baits, traps, and sometimes, by shooting. Toxic baits have to be used with caution, as they may prove hazardous to non-target domestic animals or wildlife. Avitrol and Starlicide are two commonly used baits for pigeons and starlings. Prebaiting with untreated grain will improve the efficacy of toxic baits. Pigeons and sparrows can sometimes be trapped near their loafing or feeding sites.

Table 8 - Infestation of birds in the external and internal areas of receiving, storage and production

\begin{tabular}{lclcc}
\hline \multicolumn{1}{c}{ Sectors } & Feces $^{1}$ & Feathers $^{1}$ & Live birds & Dead birds \\
\hline Hopper corn & Medium & Medium & 6 & 7 \\
Hopper flours & Medium & Medium & 5 & 8 \\
Storage of corn & High & Medium & 14 & 4 \\
Storage of flours & High & Medium & 13 & 6 \\
Pre cleaning of corn & High & Medium & 16 & 8 \\
Drying of corn & Medium & Low & 4 & 2 \\
Feed production & Medium & Low & 5 & 7 \\
\hline Iisual evaluation. & & &
\end{tabular}

To eliminate the various problems of contamination observed in the feed industry was necessary to operationalize the manufacturing procedures, with the control of critical processes, 
getting the maximum nutritional potential of food without contamination. In Table 9 was established a control plan in accordance with the principles of the Hazard Analysis and Critical Control Points (HACCP) (FAO, 2001).

Table 9 - Physical, chemical and microbiological contamination control in the feed mill

\begin{tabular}{|c|c|c|c|}
\hline Steps & Hazards & Preventive measures & $\mathrm{CCP}$ \\
\hline $\begin{array}{l}\text { Reception of raw } \\
\text { materials }\end{array}$ & $\begin{array}{l}\text { Biological: birds / rodents / insects } \\
\text { / fungi / bacteria / mites } \\
\text { Physical: foreign materials / } \\
\text { impurities / water } \\
\text { Chemical: mycotoxins }\end{array}$ & $\begin{array}{c}\text { Sampling and physical classification of } \\
\text { products / microbiological and } \\
\text { mycotoxins analysis }\end{array}$ & Yes \\
\hline $\begin{array}{l}\text { Weighing of raw } \\
\text { materials }\end{array}$ & No identified hazards & No & No \\
\hline $\begin{array}{l}\text { Internal transport } \\
\text { of raw materials }\end{array}$ & $\begin{array}{l}\text { Biological: no identified } \\
\text { Physical: foreign materials / } \\
\text { impurities } \\
\text { Chemical: no identified }\end{array}$ & $\begin{array}{c}\text { Maintenance / cleaning of the } \\
\text { equipments }\end{array}$ & Yes \\
\hline $\begin{array}{l}\text { Pre-cleaning of } \\
\text { corn }\end{array}$ & $\begin{array}{l}\text { Biological: no identified } \\
\text { Physical: foreign materials / } \\
\text { impurities } \\
\text { Chemical: no identified }\end{array}$ & $\begin{array}{l}\text { Control of the air flow / velocity and } \\
\text { inclination of the sieves }\end{array}$ & Yes \\
\hline Drying of corn & $\begin{array}{l}\text { Biological: no identified } \\
\text { Physical: foreign materials / } \\
\text { impurities / water content } \\
\text { Chemical: no identified }\end{array}$ & $\begin{array}{l}\text { Monitoring of the drying temperature, } \\
\text { water content, damaged, and burned of } \\
\text { the grains }\end{array}$ & Yes \\
\hline $\begin{array}{l}\text { Storage of raw } \\
\text { materials }\end{array}$ & $\begin{array}{l}\text { Biological: insects / fungi / } \\
\text { bacteria / mites } \\
\text { Physical: foreign materials / } \\
\text { impurities / water content } \\
\text { Chemical: mycotoxins / } \\
\text { chemical residues }\end{array}$ & $\begin{array}{l}\text { Monitoring of the relative humidity and } \\
\text { temperature of the air / water content } \\
\text { and water activity of grains / application } \\
\text { of aeration and refrigeration systems / } \\
\text { application of bromite of methyl, ozone } \\
\text { gas, and fosfine }\end{array}$ & Yes \\
\hline $\begin{array}{l}\text { Weighing of } \\
\text { microingredients }\end{array}$ & No identified hazards & No & No \\
\hline $\begin{array}{l}\text { Weighing of } \\
\text { macroingredients }\end{array}$ & No identified hazards & No & No \\
\hline $\begin{array}{l}\text { Weighing of } \\
\text { premixes }\end{array}$ & No identified hazards & No & No \\
\hline $\begin{array}{l}\text { Mixture of the } \\
\text { premixes }\end{array}$ & $\begin{array}{l}\text { Biological: no identified } \\
\text { Physical: no uniform mixture } \\
\text { Chemical: no identified }\end{array}$ & $\begin{array}{l}\text { Calibrate the equipment / regulate the } \\
\text { time of mixture }\end{array}$ & Yes \\
\hline $\begin{array}{l}\text { Grinding of } \\
\text { ingredients }\end{array}$ & $\begin{array}{l}\text { Biological: no identified } \\
\text { Physical: no uniform particle size } \\
\text { Chemical: no identified }\end{array}$ & $\begin{array}{l}\text { Use the correct sieves / regulate the } \\
\text { mills }\end{array}$ & Yes \\
\hline $\begin{array}{l}\text { Mixing of } \\
\text { ingredients }\end{array}$ & $\begin{array}{l}\text { Biological: no identified } \\
\text { Physical: no uniform mixture } \\
\text { Chemical: no identified }\end{array}$ & $\begin{array}{c}\text { Calibrate the equipment / regulate the } \\
\text { time of mixture }\end{array}$ & Yes \\
\hline $\begin{array}{l}\text { Pelletization of } \\
\text { feed }\end{array}$ & $\begin{array}{l}\text { Biological: fungi and bacteria } \\
\text { Physical: moisture / vapor / hot / no } \\
\text { uniform particle size } \\
\text { Chemical: mycotoxins }\end{array}$ & $\begin{array}{c}\text { Control of temperature, moisture and } \\
\text { pressure / regulate the sieves and } \\
\text { calibrate the equipment }\end{array}$ & Yes \\
\hline Cooling pellet & $\begin{array}{l}\text { Biological: fungi / bacteria } \\
\text { Physical: moisture / cooling } \\
\text { Chemical: mycotoxins }\end{array}$ & $\begin{array}{l}\text { Control of temperature and moisture of } \\
\text { products }\end{array}$ & Yes \\
\hline Expedition of feed & $\begin{array}{l}\text { Biological: fungi / bacteria } \\
\text { Physical: moisture of products } \\
\text { Chemical: mycotoxins }\end{array}$ & Control the moisture of products & Yes \\
\hline
\end{tabular}




\title{
4. Conclusions
}

It was concluded that the contamination physic-chemical and microbiological processing unit found in the diet adversely affect the quality of the finished feed. For quality control of products was necessary to monitor all stages of production, since the arrival of raw materials to the shipment of food. The description of the contamination and the adoption of a plan of control over the flow of production helped in making decisions and implementing appropriate control measures to control contamination.

\section{Acknowledgements}

The authors would like to thank the CAPES and CNPq foundations (Brazilian Ministry of Education) for their financial support.

\begin{abstract}
Resumo
Reduzir a contaminação na indústria de alimentos é um grande desafio para todas as empresas para obter melhores produtos e ampliar o mercado consumidor. Assim, o objetivo deste estudo foi identificar e avaliar a contaminação de uma fábrica de ração, sugerindo um plano de controle, baseado no sistema de Análise de Perigos e Pontos Críticos de Controle (HACCP). As atividades experimentais foram realizados em uma unidade de fabricação de aves, com capacidade de 1.000 ton/dia, localizado no estado de Minas Gerais, Brasil. A avaliação da contaminação foi realizada no fluxo de milho, farelo de soja e rações. Após 72 horas de operação do equipamento foram identificado níveis elevados de contaminação microbiológica na superfície dos equipamentos. A baixa qualidade física dos produtos (4,2\% impurezas, $15,83 \%$ b.u., 0,85 a.w.) favoreceu o desenvolvimento de insetos (7), fungos $\left(1,2 \times 10^{7} U_{\left.F C . g^{-1}\right)} e\right.$ bactérias $\left(1,0 \times 10^{7}\right.$ UFC. $\left.g^{-1}\right)$ nos lotes de grãos, subprodutos e rações. $O$ alto índice de contaminação nas matériasprima possibilitou a formação de micotoxinas (60,3 ppb de aflatoxinas, 28,3 ppm de fumonisinas) nos produtos finais. Nas etapas de recebimento e armazenamento das matérias-primas foram obtidos os maiores índices de contaminação microbiológica, aumentando os riscos de contaminação das rações finais. Concluiu-se, que as contaminações físicoquímicas e microbiológicas detectadas na unidade de processamento da ração comprometeram a qualidade da ração final.
\end{abstract}

Palavras-chave: indústria; processamento; produtos; qualidade.

\section{References}

AAFCO. Association of American Feed Control Official. Official Publication. Association of American Feed Control Official, 2003.

BRASIL. Portaria n ${ }^{\circ} .845$ de 8 de novembro de 1996. Estabelecem as especificações para a padronização, classificação e comercialização interna do milho. Diário Oficial, Brasília, nº.787, p.19756, 1996.

BRASIL. Ministério da Agricultura e Reforma Agrária. Regras para Análise de Sementes. Brasília, DF, 2009.

CODEX ALIMENTARIUS COMMISSION. Hazard analysis and critical control point (HACCP) system and guidelines for its application. Report of the 29th Session of the Codex Committee on Food Hygiene, Alinorm 97/13A, Appendix II. Codex Alimentarius Commission, Rome, 1996.

CORADI, P. C.; LACERDA FILHO, A. F. DE; MELO, E. C. Análise de Perigos e Pontos Críticos de Controle (APPCC) no processo de fabricação da ração. Revista Eletrônica Nutritime, v. 6, p. 1098-1102, 2009.

CORADI, P. C.; LACERDA FILHO, A. F.; MELO, E. C. Quality of raw materials from different regions of Minas Gerais State utilized in ration industry. Revista Brasileira de Engenharia Agrícola e Ambiental (Online), v. 15, p. 424-431, 2011. http://dx.doi.org/10.1590/S1415-43662011000400015

DAL BELLO, G., PADIN, S., LOPEZ, C., FABRIZIO, M. Laboratory evaluation of Chemical-biological control of the rice weevil (Sitophilus oryzae L.) in stored grains. Journal of Stored Products Research, v. 37, p. 77-84, 2001. http://dx.doi.org/10.1016/S0022-474X(00)00009-6 
DHINGRA, O. D.; SINCLAIR, J. B. Basic plant pathology methods. 2. ed. Boca Raton: CRC Press, 1995, 434p.

DUNCAN, K. E.; HOWARD, R. J. Biology of maize kernel infection by Fusarium verticillioides. Molecular Plant Microbe Interactions. n. 23, v. 1, p. 6-16, 2010. http://dx.doi.org/10.1094/MPMI-23-1-0006

ESCUDERO-GILETE, M. L.; GONZALEZ-MIRET, M. L.; MORENO TEMPRANO, R., HEREDIA, F. J. Application of multivariate concentric method system for the location of Listeria monocytogenes in a poultry slaughterhouse. Food Control. v. 18, p. 69-75, 2007. http://dx.doi.org/10.1016/j.foodcont.2005.04.020

FAO. Food and Agriculture Organization of the United Nations. Manual of the application of the HACCP system in mycotoxin in prevention and control, Roma, 2001, 118p.

HOORNSTRA, E.; NORTHOLT, M. D.; NOTERMANS, S.; BARENDSZ, A. W. The use of quantitative risk assessment in HACCP. Food Control, v. 12, p. 229-234, 2001. http://dx.doi.org/10.1016/S0956-7135(01)00019-6

HUGHES, A. M. The mites of stored food and houses. Min. Agric. Fish. Food, London, 1976, 400p.

JIAN, F.; JAYAS, D. S.; WHITE, N. D. G. Optimal environmental search and scattered orientations during movement of adult rusty grain beetles, Cryptolestes ferrugineus (Stephens), in grain bulks-suggested movement and distribution patterns. Journal of Stored Products Research, v. 45, p. 177-183, 2009. http://dx.doi.org/10.1016/j.jspr.2008.11.003

JIAN, F.; LARSON, R.; JAYAS, D. S.; WHITE, N. D. G. Three dimensional temporal and spatial distribution of adult Oryzaephilus surinamensis and Sitophilus oryzae in stored wheat under different temperatures, moisture contents, and adult densities. Journal of Stored Products Research, v. 49, p. 155-165, 2012. http://dx.doi.org/10.1016/j.jspr.2012.01.001

LORINI, I.; MIKE, L. H.; SCUSSEL, V. M. Grain storage, Campinas, SP: IBG (Institute Bio Genesis), 2002, 1000p.

MARTINEZ, E. M.; WOLOSHUK, C. Monitoring for spoilage and mycotoxins. In: Hagstrum D. W.; Phillips, T. W. Cuperus G (eds), Stored product protection. Kansas State University (in press), 2012.

MATIAS, R. S.; OLIVEIRA, W.; STEDILE, V. M. Roedores associados aos grãos armazenados. In: LORINI, I.; MIILJE, L. H.; SCUSSEL, M. V. (Org.). Grãos armazenados, Campinas: BioGenezis Instituto, 2002, p.252-287.

MILICEVIC, D. R.; SKRINJAR, M.; BALTIC, T. Real and perceived risks for mycotoxin contamination in foods and feeds: Challenges for food safety control. Toxins, v. 2, p. 572-592, 2010. http://dx.doi.org/10.3390/toxins2040572

MILLER, D. L.; HATKIN, J.; RADI, Z. A.; MAUEL, M. J. An Escherichia coli epizootic in captive mallards (Anas platyrhynchos). International Journal of Poultry Science, v. 3, p. 206-210, 2004. http://dx.doi.org/10.3923/ijps.2004.206.210

MORTIMORE, S. An example of some procedures used to assess HACCP systems within the food manufacturing industry. Food Control. v. 11, p. 403-413, 2000. http://dx.doi.org/10.1016/S0956-7135(99)00051-1

MOTARJEMI, Y.; KAFERSTEIN, F. Food safety, HACCP and the increase in food borne diseases: a paradox? Food Control. v. 10, p. 325-333, 1999. http://dx.doi.org/10.1016/S0956-7135(99)00008-0

MYERS, S. \& HAGSTRUM, D. W. Quarantine. In: HAGSTRUM, D. W.; PHILLIPS, T. W.; CUPERUS, G. Stored product protection. Kansas State University (in press), 2012.

NIGHTINGALE, K. K.; SCHUKKEN, Y. H.; NIGHTINGALE, C. R.; FORTES, E. D.; HO, A. J.; HER, Z.; GROHN, Y. T.; MCDONOUGH, P. L.; WIEDMANN, M. Ecology and transmission of Listeria monocytogenes infecting ruminants and in the farm environment. Applied and Environmental Microbiology, v. 70, p. 4458-4467, 2004. http://dx.doi.org/10.1128/AEM.70.8.4458-4467.2004

NORTHCUTT, J. K. \& RUSSELL, S. M. General guidelines for implementation of HACCP in a poultry processing plant. Bulletin 1155, University of Georgia College of Agricultural and Environmental Sciences, U.S. Department of Agriculture, Athens. 2003.

NUKENINE, E. N.; MONGLO, B.; AWASON, I.; NGAMO, L. S. T.; TCHUENGUEM, F. F. N.; NGASSOUM, M. B. Farmer's perception on some aspects of maize production, and infestation levels of stored maize by Sitophilus zeamais in the Ngaoundéré region of Cameroon. Cameroun J. Biol. Biochem. Sci., v. 12, p. 18-30, 2002. 
PARK, S. H.; ARTHUR, F. H.; SCOTT, R. B.; SCHOBER, T. J. Impact of differing population levels of Rhyzopertha dominica (F.) on milling and physicochemical properties of sorghum kernel and flour. . Journal of Stored Products Research, v. 44, p. 322-327, 2008. http://dx.doi.org/10.1016/j.jspr.2008.02.008

PATRICK, M. E.; ADCOCK, P. M.; GOMEZ, T. M.; ALTEKRUSE, S. F.; HOLLAND, B. H.; TAUXE, R. V.; SWERDLOW, D. L. Salmonella enteritidis infections, United States, 1985-1999. Emerging Infectious Diseases Journal. v. 10, p. 1-7, 2004. http://dx.doi.org/10.3201/eid1001.020572

PETTERSSON, H. Controlling mycotoxins in animal feed. In: MAGAN, N.; OLSEN, M. (Eds.), Mycotoxins in Food. Detection and Control. CRC Press, Woodhead Publishin Limited, England, p.262-304, 2004.

ROPKINS, K. \& BECK, A. J. Evaluation of worldwide approaches to the use of HACCP to control food safety. Trends Food Science and Technology, v. 11, p. 10-21, 2000. http://dx.doi.org/10.1016/S0924-2244(00)00036-4

SCHOENBAUM, M. A.; HALL, S. M.; GLOCK, R. D.; GRANT, K.; JENNY, A. L.; SCHIEFER, T. J.; SCIGLIBAGLIO, P.; WHITLOCK, R. H. An outbreak of type C botulism in 12 horses and a mule. Journal of the American Veterinary Medical Association, v. 217, p. 365-368, 2000. http://dx.doi.org/10.2460/javma.2000.217.365

SENTHILKUMAR, T.; JAYAS, D. S.; WHITE, N. D. G.; FREUND, M. S.; SHAFAI, C.; THOMSON, D. J. Characterization of volatile organic compounds released by granivorous insects in stored wheat. Journal of Stored Products Research, v. 48, p. 91-96, 2012. http://dx.doi.org/10.1016/j.jspr.2011.09.006

SINDIRAÇÕES. Sindicato Nacional da Indústria de Alimentação Animal. The good practices of fabrication for establishments of animal nutrition products. São Paulo, 2012.

SOFOS, J. N. Challenges to meat safety in the 21st century. Meat Science, v. 78, p.3-13, 2008. http://dx.doi.org/10.1016/j.meatsci.2007.07.027

SPECK, L. M. Compendium of Methods for the Microbiological Examination of Foods. 2th Ed. Washington, DC: American Public Health Association, 1984.

SUBRAMANYAM, B. H.; ROESLI, R.; BRUESCH, J.; MENON, A. Sanitation and pest management, In: SCHOFIELD, E. K. (ed.), Feed manufacturing technology V. American Feed Industry Association, Arlington, Virginia, p. 415-431, 2005.

SURAK, J. G. The certified quality auditor's HACCP handbook. American Society for Quality, Milwaukee, WI. 2002.

TOMPKIN, R. B. HACCP in the meat and poultry industry. Food Control. v. 5, p. 153-161, 1994. http://dx.doi.org/10.1016/0956-7135(94)90075-2

TURHAN, S.; OZBAG, B. C.; ETIN, B. C. Analysis of the broiler sector: the case of price competition. Agricultural Research, v. 49, p. 431-437, 2006.

USDA. United States Department of Agriculture. Design criteria and test performace specifications for quantitative aflatoxin and fumonisin test kits. Federal Grain Special Service Quality Assurance and Research Division, 1998.

Submetido em 07 fev. 2013, Aceito para publicação em 10 nov. 2013. 